\title{
Beijing to Taipei, via Singapore
}

From the 2015 Summit to the 2016 Taiwanese Elections

\section{Stéphane Corcuff}

Translator. Michael Black

\section{(2) OpenEdition}

\section{Journals}

Electronic version

URL: http://journals.openedition.org/chinaperspectives/6925

DOI: $10.4000 /$ chinaperspectives. 6925

ISSN: 1996-4617

\section{Publisher}

Centre d'étude français sur la Chine contemporaine

\section{Printed version}

Date of publication: 1 March 2016

Number of pages: $55-58$

ISSN: 2070-3449

\section{Electronic reference}

Stéphane Corcuff, «Beijing to Taipei, via Singapore », China Perspectives [Online], 2016/1 | 2016, Online since 01 March 2016, connection on 15 September 2020. URL : http://journals.openedition.org/ chinaperspectives/6925 


\title{
Beijing to Taipei, via Singapore
}

\author{
From the 2015 Summit to the 2016 Taiwanese Elections
}

\author{
STÉPHANE CORCUFF
}

7 he announcement of the summit held between the Chinese and Taiwanese Presidents on 7 November 2015 in Singapore had the effect of a thunderclap in Taipei, such was the surprise at the lack of prior information provided by the authorities on both shores. (1) Various causes have been advanced for the holding of the summit, an idea that has been discussed for 20 years, but which had never taken place due to the many obstacles to its organisation on both sides.

Several explanations have been put forward in the public debate in Taiwan: the desire of Ma Ying-jeou, Taiwan's outgoing president, to carve out for himself a place in history; the two presidents' objective of restricting the future policy of the favourite in the polls, the president of the main opposition party, Tsai Ing-wen; the determination of the Chinese President, Xi Jinping, to make progress on the Taiwan issue; or the development of a common All-China front against Washington on the issue of the South China Sea.

In this article, we focus on yet another cause that has been put forward, which doesn't exclude the others. It is China's desire to intervene indirectly in Taiwan's then on-going campaign for the presidential and legislative elections of 16 January 2016, the outcome of which, a double defeat of the Kuomintang (KMT), was by then no longer in doubt. This explanation does not conflict with the tendency to see the two parties, the Chinese Communist Party (CCP) and the KMT, as determined to take a step forward before the return of the Democratic Progressive Party (DPP) to power. We examine here the hypothesis, advanced by many, that the Beijing authorities may have eventually agreed to the organisation of the summit in order to bolster $X i$ Jinping's image in China on the Taiwan issue and try to influence a critical situation for China in the Strait (the prospect of a historic defeat of the KMT, a circumstantial ally of the CCP and a unifying party, which during the eight-year presidency of Ma Ying-jeou had conducted a conciliatory policy towards China). (2)

In the absence of testimony from those directly involved in the negotiation regarding the motives of the two presidents, we simply suggest here that it was China's concerns about the predicted return of the Democratic Progressive Party to the presidency of the Republic and its probable victory in the legislature, and the context of an irrepressible strengthening of the island identity in attitudes in Taiwan, that led China to overcome its reluctance to organise a summit that presented uncertain benefits and definite disadvantages.

However, we focus less on the hypothesis of a cost-benefit analysis that may have pushed Beijing to overlook the costs in order to obtain the benefits, than more specifically on the use of an emergency wild card. According to this interpretation, Beijing may have made a kind of "hail Mary pass," hoping that this indirect intervention would positively influence the KMT's campaign without the inevitably negative impacts for China of such a summit proving disastrous for its Taiwan policy in the world, without, however, being too confident of its chance of success. It appears that not only did the intervention not benefit the KMT electorally, but also that the international benefits derived by Taiwan from such a summit proved to be real, demonstrating that China cannot control the Taiwanese game: neither the carrot nor the stick seem to have any effect in the face of the affirmation of a Taiwanese nation. China knew it for sure, but could Beijing afford to stand still?

After first recalling the origin of the idea of a summit between the two presidents and the failure of governments on both shores to organise it previously, we briefly examine a few causes that have been put forward to explain its suddenly being held, prior to finding that only a critical situation could have led Beijing to give the summit a try when it presented so many disadvantages for China.

\section{The meeting: An old idea}

In January 1995, in a speech on Taiwan policy in eight points (Jiang badian 江八點), Chinese President Jiang Zemin discussed the possibility of the leaders of both sides meeting, suggesting a willingness to discuss the status under which they could meet. As Jean-Pierre Cabestan analysed it then, Jiang's openings were nevertheless all relative and remained constrained by the rigid framework of a People's Republic that refused to recognise the existence and sovereignty of the Republic of China. ${ }^{(3)}$

Since then, no summit had been organised. Any discussion was indeed stalled by China's refusal to invite the Taiwanese leader in his capacity as President of the Republic of China, its reluctance to organise the meeting in a third country, and Taiwan's refusal to send its President to the territory of the so-called "continental" China unless he was recognised as head of state. In addition, several political events in the 1990s and 2000s made the prospect of a meeting more remote: Lee Teng-hui's long considered and uncompromising response to the "Eight Points"; his visit to the United States a few months later, which triggered Chinese anger and the 1995-1996 missile crisis; finally the election in 2000 of Chen Shui-bian of the DPP, who opposed unification: all these events caused China's position to be even more uncompromising, which was especially palpable during the end of Lee's tenure and during the two mandates of Chen Shui-bian. The presidency

1. The information was made public only four days before the summit, on an opposition platform, the website of the Liberty Times, on 3 November late in the evening: "Dujia: Ma zongtong qi ri mi fang Xinjiapo 'Ma-Xi hui' bu qi er yu" (Exclusive: President Ma's Secret Visit to Singapore for a "Ma-Xi Summit" by Coincidence), Liberty Times website, 3 November 2015, http://news.ltn.com.tw/news/politics/breakingnews/1496483 (accessed on 30 January 2016).

2. Among other references, see "The Emperor's Descendants," The Economist, 14 November 2015, www.economist.com/news/asia/21678247-smiles-and-handshakes-usher-what-will-be-rockyperiod-china-taiwan-relations-emperors (accessed on 27 January 2016).

3. Jean-Pierre Cabestan, "Vers un sommet Jiang Zemin - Lee Teng-hui ? À propos du discours en huit points de Jiang Zemin et de la réponse en six points de Lee Teng-hui" (Towards a Summit between Jiang Zemin and Lee Teng-hui? On the Eight-point Speech by Jiang Zemin and the Six-point Response by Lee Teng-hui), Perspectives chinoises, No. 28, 1995, pp. 43-49. 
of Ma Ying-jeou (2008-2016), which saw the return to power of the significantly more pro-unification Kuomintang, certainly led to a modest improvement in relations, but not to any change on the core issue of sovereignty, while the prospect of unification appeared ever more remote.

Thus the current Chinese President Xi Jinping declared in October 2013, shortly after his accession as head of state, that reunification with Taiwan "could not be perpetually put off from generation to generation" (buneng yidai yidai chuan xiaqu), (4) causing a wave of questions about his intentions, which have not been very explicit in this regard, particularly as to how he would go about solving a problem for which none of his predecessors had been able to find a solution. However, while brandishing a verbal threat, he also announced that he supported the meeting of the "heads of institutions of both parties" (shuangfang zhuguan bumen fuzeren) to "conduct negotiations on an equal footing with Taiwan" (tong Taiwan jinxing pingdeng xieshang). ${ }^{(5)}$

Did he already mean by this that it was possible to take another look at the matter of a meeting between the presidents, echoing the eighth point set out by Jiang Zemin 18 years earlier? The careful wording of $\mathrm{Xi}$ Jinping at the time made it impossible to know for sure, but the organisation of the summit two years later appears to confirm that he favoured it, or at least that he had come around to the idea. Why was the summit finally organised? There are probably several reasons, and testimonies and revelations that may be published in the future will help us to sharpen the analysis.

\section{The reasons put forward}

First of all, one might be tempted to see Xi Jinping, involved on many domestic and international fronts, as seeking a breakthrough in the difficult Taiwanese question at a time when the growth of the Chinese economy is slowing down. The situation in the Strait might have seemed propitious: Ma's two terms of office were those of a relative relaxation in the Strait, and meeting the leader of the KMT, a party that is both brother and enemy, at a time of reconciliation might enhance $X i$ Jinping's stature. This is one of the causes put forward by The Economist. ${ }^{(6)}$ But then why do it so late, when Ma Ying-jeou had made no secret at several points during his two terms of his willingness to meet with his counterparts $\mathrm{Hu}$ Jintao and $\mathrm{Xi} \mathrm{Jin-}$ ping? It seems that the tardiness of the summit and its organisation seven months before the end of Ma's mandate at least partially discredit this argument, unless it is taken into consideration along with other explanatory causes.

In Taiwan, many Internet users interpreted the repeated efforts of the Taiwanese President in view of the summit as an attempt to carve for himself, by means of this meeting, a historic stature that would distract from the unfavourable image left by his two terms as head of state: his economic and social record is heavily criticised in Taiwan, and his approval ratings never exceeded $20 \%$ during the last three years of his term. ${ }^{(7)}$ However, this is a political argument related to party politics, and the fact that it is widespread in Taiwan does not make it indisputable, even though such an explanation is as difficult to disprove as it is to confirm.

Some have seen the Singapore meeting as a strategy by Beijing to try to make an ally of Taipei (or more precisely, the KMT) in an All-China nationalist front facing the United States on the sensitive issue of sovereignty in the South China Sea, where Taiwan maintains a territorial claim in the name of its regime identity as the Republic of China. ${ }^{(8)}$ But again, this argument is not entirely convincing. Five weeks after the summit, and three weeks before the Taiwan elections of 16 January, US Congress decided to allow the Obama administration to make its third and final sale of weapons and major military equipment to Taiwan. Since such a sale could not take place before the end of MaYing-jeou's presidency, and while the coming electoral defeat of the KMT was already almost certain at the time of the announcement, we may conjecture that the United States did not see in this summit a risk of an anti-US united front in the South China Sea, confirming the officially positive take on the summit indicated by the White House spokesman three days before the meeting. ${ }^{(9)}$ The surprise created by Ma Ying-jeou's visit to the island of Itu Aba on 28 January did lead observers to wonder again about the possibility that the two presidents discussed the issue during the summit, yet it is unclear that this visit was anything more than a simple reaffirmation of sovereignty by an outgoing president, just as his predecessor, who belonged to the DPP, had done just before leaving office in February 2008.

\section{Shared and diverging interests}

In the aggregation of causes that led to the decision to hold an international meeting between two parties, neither of which has established absolute control over the destiny of the other, at least two configurations leading to the decision can be considered. The first is where respective interests diverge, which led the two parties to discuss their goals in order to seek a minimum consensus; the second is where interests converged at the outset on one or more points, and the existence of a minimum initial consensus that allowed the meeting to result in political decisions.

Yet, this is in fact ideal-types. The Economist, in its analysis of the summit, adopted that one clear distinction by opposing the two parties' interests, and concluded that with the two interpretations completely opposed to each other, "They cannot both be right." (10) Yet the distinction between these two types of situations is, in fact, rarely that clear, as it only requires the two parties to be willing to reach a minimal agreement between their diverging interests for them to find a consensus to start with. This was the case in Singapore.

It is true that Chinese and Taiwanese interests on both shores are divergent: while the People's Republic of China wants reunification and the end of the legal existence of the Republic of China, the latter seeks to ensure its international survival, and to protect itself from the irredentist aims of its neighbour. However, when the KMT was in power, Taiwan's policies converged with China's on the ultimate goal of reunification, based on the belief that Taiwan and China belong to the same nation, a point that Ma and Xi restated clearly in Singapore, only to see Taiwan's pro-independence camp strongly resenting it. Did a particular congrega-

4. "Huiwu Xiao Wanchang Xi Jinping: zhengzhi wenti buneng yidai yidai chuan xia qu" (In an Interview with Vincent Siew, Xi Jinping indicates that the Political Problem [in the Taiwan Strait] Cannot Be Passed On from Generation to Generation), ET today, 7 October 2013, http:// www.ettoday.net/news/20131007/279079.htm\#ixzz3wvcp8nhC (accessed on 27 January 2016). 5. Ibid.

6. "The Emperor's Descendants," art. cit.

7. "Taiwan Mood Barometer Survey" by the private company Taiwan zhibiao mindiao (Taiwan Indicators Survey Research), www.tisr.com.tw/?p=6100 (accessed on 25 January 2016).

8. "Bie nao le! Ma-Xi hui de zhongdian zai Nanhai" (Stop Making Noise About Nothing! The Central Point of the Summit Lies in the South China Sea), Lianhe xinwenwang, 5 November 2015, http://theme.udn.com/theme/story/8959/1294744 (accessed on 27 January 2016).

9. "Ma-Xi hui Meifang shiqian zhiqing baigong biaoshi lejian" (The United States Were Informed in Advance of the Meeting between Ma and Xi and the White House Expresses a Positive Point of View), TVBS Xinwen, http://news.tvbs.com.tw/politics/news-624284 (accessed on 27 January 2016).

10. "The Emperor's Descendants," art. cit. 
tion of interests, a unique event, or a particular context finally make the summit possible?

Two decades ago, in his analysis of Jiang Zemin's "Eight Points" published in Perspectives chinoises, Jean-Pierre Cabestan spelled out in the following terms the interest of such a meeting for both parties, while indicating that the obstacles were numerous: "In this way, the Taipei government could hope, in any event, to enhance its international stature, and Beijing would be able to consider opening real political negotiations." (11)

After 20 years, during which the situation in the Strait has changed considerably, especially because of internal political developments in Taiwan, is this framework still valid? It is clear that for China, the prospect of opening political negotiations with Taiwan has become more remote, while through the meeting between the two presidents in Singapore, Taiwan was effectively able to gain international visibility. The Taiwanese president in fact appeared before a large audience of international journalists who addressed him as "Mr. President" or "President Ma," which had never happened before.

\section{A critical electoral situation}

Given that the Taiwanese president was in no position to conduct secret negotiations with Beijing (which would have undermined the sovereignty of the regime over which he presided) and that the summit was likely to turn to the media advantage of Taiwan, which was presented as seeking peace, what could be China's interest in agreeing to the Xi-Ma meeting seven months from the end of Ma's mandate?

The proximity between the summit in early November 2015, the Taiwanese elections in January 2016, the subsequent inauguration of new members of the legislature (1 February), and the inauguration of the new president (20 May) cannot fail to raise the question of a possible connection between the meeting, the Taiwanese electoral calendar, and the perspective of a major change in the political and geopolitical situation in Taiwan, and possibly in the Strait.

To speak only of the presidential election, the KMT candidate Hung Hsiuchu, who was replaced shortly before the summit in Singapore, had for several months been constantly predicted as heading for defeat, with between $12.7 \%$ and $20.5 \%$ support in the polls, ${ }^{(12)}$ always trailing far behind Tsai Ingwen. Her replacement at the end of October by KMT chairman Chu Li-lun had no effect on the poll results. The elections to the chamber - the Legislative Yuan - also threatened the imminent loss by the KMT of the absolute majority it has held ever since the legislative election of 1947.

If such a prospect was enough to be a source of anxiety for China, the summit can be interpreted as the result of the perception by both parties of an exceptional situation playing against their interests and the desire of both presidents to make a strong symbolic step forward before a DPP government come into office. Moreover, this was based on an initial consensus between the two parties: Taiwan's belonging, according to the KMT, to the Chinese nation, as expressed in the agreement of the Party to the "1992 Consensus," the interpretation that the KMT and the CCP gave to the meeting of their delegates in Singapore in 1992, and based on the principle that there is only "one China" (yige Zhongguo 一個中國). Furthermore, it is likely to be a calculation, rather than an oversight, which would explain why Ma Ying-jeou, to the great displeasure of the Taiwanese, did not mention before Xi Jinping the further interpretation of the "1992 Consensus," which the KMT has promoted, but which irritates the People's Republic: "One China," yes, but with "respective interpretations" (gezi biaoshu 各自表述). We could see in this the results of the respective interests of each party, and their common interest in unification, the decision by Ma Ying-jeou not to offend Xi Jinping, and perhaps also a prior request from the Chinese side during the negotiations to organise the summit for Ma to stick to the Beijing position.

\section{A summit without major follow-up}

Can policy decisions taken in the area of their mutual relations by the parties to the Singapore summit and announced after the event confirm the hypothesis of a link between the summit, the pre-election situation of the KMT, and China's concerns about the unknown post-KMT in Taiwan, while at the same time providing information about the content of the negotiations behind closed doors?

Two decisions establishing closer links in the Strait and announced shortly before the election may possibly lead one to believe so: the establishment of a hotline between the two governments announced on 30 December; (13) and the first authorisations, previously denied by Beijing, for Chinese tourists to transit through Taiwan en route to third countries, on 6 January. ${ }^{(14)}$ The Presidency in Taipei did not fail to see these as the result of "relaxation" and a direct consequence of the Singapore summit - going so far as to credit the latter, in its enthusiasm, for a release of spies that had apparently taken place three weeks before the summit itself. ${ }^{(15)}$ The fact that, according to the Taiwanese press, the hotline appears to have been shut down by the Chinese side after the DPP victory would tend to confirm that China was merely seeking to influence the vote, ${ }^{(16)}$ while closing it would not be a positive sign from Beijing's side.

If all this was an attempt to influence Taiwan's elections, it would be wrong to see it as effective. The meeting in Singapore had already provoked sharp criticism in Taiwan against Ma Ying-jeou, especially for his "culpable neglect" before Xi Jinping on the "1992 Consensus," so that the summit had increased concern in a majority of Taiwanese about their president's China policy. (17) Surveys conducted immediately after the summit also showed that the

11. Jean-Pierre Cabestan, "Vers un sommet Jiang Zemin - Lee Teng-hui ? À propos du discours en huit points de Jiang Zemin et de la réponse en six points de Lee Teng-hui" (Towards a Summit between Jiang Zemin and Lee Teng-hui? On the Eight-point Speech by Jiang Zemin and the Sixpoint Response by Lee Teng-hui), art. cit.

12. "Taiwan zhibiao mindiao Song Chuyu shouci luohou Hong Xiuzhu" (According to the Taiwan Mood Barometer Survey, Support for Soong Chu-yu Falls Behind that for Hung Hsiu-chu for the First Time), Storm media, 14 July 2015, www.storm.mg/article/65343 (accessed on 27 January 2016).

13. "Le téléphone rouge Taipei-Pékin est fruit de la rencontre Ma-Xi, affirme la présidence de la République" (The Hotline between Taipei and Beijing is a Result of the Meeting between Ma and $\mathrm{Xi}$, Says the Presidency of the Republic), Taiwan Info, 31 December 2015, http://taiwan info.nat.gov.tw/ct.asp? $x \mid$ tem $=240825 \& c t N o d e=2248 \& m p=4$ (accessed on 27 January 2016).

14. Three Chinese cities were first "opened" as a test: Chongqing, Kunming, and Nanchang. Cf. "Zhongguo pianmian xuanbu dui Tai liang li duo Chen Qimai zhiyi: xuanju kaoliang" (China Unilaterally Announces Measures with a Double Benefit for Taiwan. [Member of Legislative Yuan] Chen Chimai is Sceptical: [It's More Likely to Be] An Electoral Calculation), Sanli xinwen wang, 7 January 2016, www.setn.com/News.aspx?NewsID=116817 (accessed on 27 January 2016).

15. "Lishixing tupo liang'an mimi huan fu" (A Historic Breakthrough: The Two Shores Exchange Prisoners), China Times, 30 November 2015, www.chinatimes.com/newspapers/20151130000317260102; "China Releases Taiwanese Spies," Taipei Times, 1 December 2015, www.taipeitimes. com/News/front/archives/2015/12/01/2003633726 (both URLs were accessed on 27 January 2016).

16. "Duibuqi, nin bo de haoma... xuanhou liang'an rexian Zhongguo bu jie" (Sorry, The Number You've Dialed... China Doesn't Answer the Hotline Since the Election Is Over), Liberty Times Net, 28 January 2016, http://news.ltn.com.tw/news/politics/breakingnews/1587035 (accessed on 13 February 2016).

17. According to the survey, $52.7 \%$ of respondents felt that Ma was not able to defend the sovereignty and interests of their country, against $30.2 \%$ who believed the opposite. "Taiwan Mood Barometer Survey" by the private company Zhibiao mindiao Taiwan (Taiwan Indicators Survey Research), art. cit. Another criticism, formulated by Gerrit van des Wees in the Taiwan Communiqué, was that the summit replaced "Taiwan-China relations in the anachronistic framework of the decades-old rivalry between the Kuomintang and the CCP, and negate[d] the democratic transition Taiwan has experienced." Cf. Taiwan Communiqué, No. 154, January 2016, p. 10. 
meeting had not benefited the KMT presidential candidate, Chu Li-lun, and on the contrary, had slightly increased support for the DPP candidate. As for its influence on the election itself, on 16 January, the two events were too distant at the time of the vote, and the electoral debate too focused on reform in Taiwan, to prejudge any significant impact on the election itself. ${ }^{(18)}$

\section{Conclusion}

While the Ma Ying-jeou government insisted on showing that China was moving forward following the summit, it is actually rather by its discretion that China seems to shine in its attempt, if any, to influence the election, at least in comparison with the missile crisis that preceded the 1996 election, and the suspicions of Chinese pressure on major Taiwanese businessmen who had publicly opposed Tsai's candidacy in 2012. Everything seems to indicate that China had also understood the final outcome and the dan- ger of a too visible response. Beijing did resume, as in 2012, the principle of indirectly subsidising - through associations of Taiwanese businessmen in China - plane tickets for Taishang ${ }^{(19)}$ to return to Taiwan to vote, which by the way led an authoritarian regime to subsidise a democratic election in order to try to influence it. Yet, this was done without much enthusiasm and relatively discreetly. ${ }^{(20)}$ As for the few major Taiwanese business leaders who had publicly taken sides in 2012 through statements to the media and advertising inserts in the press, this time all refrained from public intervention, a sign of China's very narrow margin of manoeuvre on this issue, unless it were to resort to an expensive and risky military intervention.

\section{Translated by Michael Black.}

IStéphane Corcuff is director of the CEFC branch in Taipei.

Room B110, Research Center for Humanities and Social Sciences, Academia Sinica, Taipei 11529, Taiwan (scorcuff@cefc.com.hk).
18. Stéphane Corcuff, "Chine-Taiwan : après Singapour" (China-Taiwan: After Singapore), Asialyst, 25 November 2015, https://asialyst.com/fr/2015/11/25/chine-taiwan-apres-singapour (accessed on 27 January 2016).

19. On the notion of Taishang, cf. the article by Gunter Schubert, Lin Rui-hua, and Tseng Yu-Chen in this issue of China Perspectives (pp. 29-36).

20. There was little comment in the media and on social networks about the question, which was noted by observers. It seems that the amount of the subsidy provided to businessmen who wished to go home to vote was considerably reduced this time around. Cf. "Zhe yi ci, haiyou duoshao dalu Taishang hui Tai toupiao?" (This Time Around, How Many Taishang Will Go Home to Taiwan to Vote?), The Initium, 31 January 2015, https://theinitium.com/article/20151231-taiwan-presidential-election-taiwan-businessmen (accessed on 27 January 2016). 